\title{
4. 当教室における内視鏡的手術の現状と一工夫
}

（名古屋保健衛生大学医学部産科婦人科学教室）

\author{
廣田銥 - 馬島秀泰 - 福島穣
}

先にも示した如く, 当教室においても1981 年 8 月より腹腔鏡が導入され, その総数も 41 例を 数えるに至った. その中でも, 手術的操作を加え たものは 11 例であり，ちちわけは，P.C.O. 3 例， 生検 2 例, P.F.A, P.T.A. を含告瘉着䟝離術 4 例, 不妊手術 2 例であった。 これは全症例数の $26.8 \%$ にあたり，不妊手術 2 例を除けばすべて不妊症に なされたものであった，各症例について，スライ ドを示し報告する。

\section{(症例 1)}

25 才, $0-0-0=0,3$ 年の不妊期間を主訴として 来院, 卵管疎通検査で異常なく, 第 I 度無月経, HMGープレマリンテスト陰性で左附属器に小鶏 卵大ののら腫を触れた為, P.C.O.を疑い腹腔鏡施 行

右卵巣は, 超鳵卵大, 左卵巣は鳩卵大と伴に腫 大, 白膜厚くその下に多数ののう胞を認めた. 生 検及び止血操作を加えた.

(症例 2)

32 才， $0-0-0=0, \quad 5$ 年の不妊期間を主訴として 来院, 原発性の第II 度無月経で, LH-RH テスト は下垂体性, HMG に汪とんど反応を示さず。子 宮卵管にも特くに異常を認めない為腹腔鏡施行.

左右卵巣とも萎縮傾向を認め, 特くに右卵巣に
それが著明であり，病理組鐡所見でも卵胞の成熟 度が低く, 汪とんどのものは原始卵胞のの段階で とどまっていた。生検及び止血操作を加えた。

(症例 3 )

21 才， $0-0-1=0,1$ 年半の不妊を主訴として 来 院, H.S.G. 澷て左卵管水腫様変化と右卵管閉鎖の 所見を得た為腹腹鏡施行.

左卵管周囲に大網の癒着を認めた。腹腔鏡下に 䟝離, 止血操作を加えた.

(症例 4 )

27 才, 3-0-0=3, 不妊手術希望にてバイポーラ による電気凝固を加えた.

生検部位及び䟝離部位よりの出血点の確認は, 従来, 鉗子の先にて血液を“奴う”ょうにして 行っていたが，とさに非常に困難さを覚劣る為， 現在我々は, 眼科用の MQAをグラスビングフォ 一セプスの先につけ使用している。これにより， 出血点及び止血の確認は容易に，また確実にでき 大変重宝している.

近年，腹腔鏡の普及開発も目をみはるものがあ り，単なる形態観察のみにとどをらず，各種鉗子 を使った手術操作, 組織診, 細胞診など, 今後多 方面にわたりその利用範囲が広げられていくもの と思われる。 